\title{
Analysis of balancing of six-cylinder in-line two-stroke internal combustion engines
}

\begin{abstract}
Simple relations describing the resultant moments of inertia forces of the first and second order for all sixty possible configurations of the crankshaft in two-stroke four-cylinder engine have been derived in the paper. A comparative analysis of the crankshafts with different arrangements of cranks have been carried out with respect to the resultant moments of the first and second order inertia forces. The comparison has been carried out for two values of the crank throw to connecting rod length ratio, namely $\lambda=0.3$ and $\lambda=0.5$. The outcomes of the comparative analysis indicate that irrespective of the $\lambda$ value, within the range of its values having practical meanings, the arrangement of cranks 1-5-3-4-2-6 is the best. As a result of $50 \%$ balancing of the moment of the first order inertia forces the differences between various configurations of the crankshaft are significantly reduced and configuration 1-4-2-6-3-5 equals with respect to balancing with the commonly used configuration 1-5-3-4-2-6.
\end{abstract}

Key words: IC engines, crank gears, balancing

\section{Analiza wyrównoważenia dwusuwowych sześciocylindrowych silników rzędowych}

\begin{abstract}
W pracy wyprowadzono proste zależności opisujące przebieg momentu od sit bezwładności pierwszego i drugiego rzędu dla wszystkich 60. wariantów wałów korbowych w silniku sześciocylindrowym 2-suwowym rzędowym. Dokonano analizy i porównania poszczególnych wariantów z punktu widzenia momentów wypadkowych od sił bezwładności pierwszego $i$ drugiego rzędu. Porównania dokonano dla dwóch wartości parametru mechanizmu korbowego $\lambda=0,3 i$ 0,5. Wyniki analizy porównawczej pokazuja, że niezależnie od wartości parametru $\lambda, w$ zakresie wartości tego parametru mających praktyczne znaczenie, konfiguracja 1-5-3-4-2-6 jest najlepsza. W następstwie wyrównoważenia składowej pierwszego rzędu momentu od sit bezwładności różnice w jakości wyrównoważenia ulegaja znacznemu zmniejszeniu i dla $\lambda=0,5$ konfiguracja 1-4-2-6-3-5 zrównuje się pod tym względem z wykorzystywana powszechnie w praktyce konfiguracja 1-53-4-2-6.
\end{abstract}

Słowa kluczowe: silniki spalinowe, mechanizmy korbowe, wyrównoważanie

\section{Introduction}

In multi-cylinder two-stroke in-line engines as well as in four-stroke engines with uneven number of cylinders, excluding two-cylinder engines, the inertia forces in reciprocating motion are mutually balanced. In two-stroke engines, however, the secondary forces are not balanced. Unlike the inertia forces, their moments are not balanced regardless of the engine design.

Arrangement of cranks along the crankshaft of an IC engine can be made in different ways and has impact on the resultant moment of inertia forces. It follows from relation (1) in work [1] that the cranks in a six-cylinder engine may be arranged in 60 different ways. In order to determine the best arrangement of the cranks (the best crankshaft configuration) and thereby the firing order (the arrangement of cranks explicitly determines the firing order and vice versa) a simple graphic pattern (method) is applied which was presented in work [1]. With the use of that pattern from the all theoretically possible arrangements of cranks the one can be selected for which the resultant vector of the primary and secondary inertia forces in reciprocating motion as well as the resultant vector of the moment of the forces of the revolving masses have the minimum moduli. In this method the resultant moment of the secondary forces is

\section{Wstęp}

W silnikach wielocylindrowych rzędowych dwusuwowych, a także czterosuwowych o nieparzystej liczbie cylindrów, z wyjątkiem silników 2-cylindrowych, siły bezwładności $\mathrm{w}$ ruchu postępowo-zwrotnym wzajemnie się równoważą. W silnikach 2-cylindrowych nie równoważą się siły bezwładności drugiego rzędu. Inaczej jest z momentem wypadkowym od sił bezwładności, który niezależnie od rozwiązania konstrukcyjnego jest zawsze wektorem niezerowym.

Usytuowanie wykorbień wzdłuż wału korbowego silnika spalinowego może być różne i wpływa na wielkość wypadkowego momentu od sił bezwładności. Jak wynika z zależności zamieszczonej w pracy [1], silnik 6-cylindrowy stwarza możliwość ustawienia wykorbień wału sześćdziesięcioma różnymi sposobami. Do określenia najlepszego sposobu ustawienia wykorbień (konfiguracji) wału korbowego silników 2-suwowych, a także 4-suwowych o nieparzystej liczbie cylindrów, a tym samym ustalenia także kolejności zapłonu (konfiguracja wału korbowego w tej grupie silników jednoznacznie określa kolejność zapłonu i na odwrót), stosuje się prosty schemat graficzny przedstawiony w pracy [1]. Za pomocą tego schematu spośród wszystkich teoretycznie możliwych konfiguracji wału wy- 
totally neglected. For a six-cylinder engine these conditions are met by the arrangement of cranks 1-5-3-4-2-6. Certainly for that reason in the available literature the formulae for the total moment of inertia forces in reciprocating motion are not given $[3,4]$ but only amplitudes of the primary and secondary inertia forces. Such an approach is justified for the crank gears for which the ratio between the crankshaft throw and connecting rod length does not exceed a certain value dependent on the number of cylinders. Meanwhile long-stroke engines have been produced for over 25 years with $\lambda$ value close to 0.5 .

The main purpose of this work is to examine whether this simple method of selecting the optimum configuration of the crankshaft is still valid for a six-cylinder engine quite often used in shipbuilding, particularly in the engines with big values of $\lambda$, and possibly to determine the critical value above which this simple graphic method loses its validity. It is worth noticing in this context, as established in [1], that for two-stroke four-cylinder engines the critical value of $\lambda$ above each this simple graphic pattern loses its validity equals 0.527 .

The knowledge on how far the subsequent configurations of the crankshaft differ from the best one with respect to the maximum value of the resultant moment of inertia forces in reciprocating motion can also be beneficial. When a pulse turbocharging system is used the best engine balance must sometimes be sacrificed for better turbocharging. Equally interesting may be the comparison of the individual configurations of the crankshaft after $50 \%$ balancing of the maximum moment of the primary inertia forces with the aid of masses attached to it.

\section{Mathematical relations describing the primary and secondary forces in a six-cylinder engine}

In a six-cylinder engine the both resultant vectors of inertia forces either in reciprocating or rotational motions are zero vectors. Only the vectors of the moments of the inertia forces remain unbalanced.

By using the method of the fictitious vectors presented in work [2] and made more lengthy in [1] it is possible to derive relations for the resultant moments of the primary and secondary inertia forces for individual configurations of the crankshaft. As a reference point for the moments of the inertia forces analysis the intersection of the axis of the first cylinder with the crankshaft axis of rotation have been chosen as well as an equal distance between the cylinders axis assumed.

Under these assumptions the modulus of fictitious vectors of moments of primary and secondary inertia forces divided by $m_{p} R \omega^{2} a$ and $m_{p} R \omega^{2} \lambda a$ respectively are presented by the relations:

$$
\begin{aligned}
& \left|\mathbf{B}_{w \mathbf{w j}}^{\prime}\right|=\mathrm{j}-1 \\
& \left|\mathbf{B}_{\mathrm{wj}}^{\prime \prime}\right|=\mathrm{j}-1
\end{aligned}
$$

and the resultant moments (actual) of the primary and secondary forces by relations (3) and (4) respectively: biera się tę, dla której wektor wypadkowy momentów od sił bezwładności pierwszego rzędu i wektor wypadkowy od sił bezwładności w ruchu obrotowym mają najmniejszy moduł. $\mathrm{W}$ tej metodzie pomija się całkowicie wypadkowy moment od sił bezwładności drugiego rzędu. Te warunki dla silnika 6-cylindrowego spełnia wał korbowy o konfiguracji 1-5-34-2-6. Zapewne dlatego w dostępnej literaturze silnikowej $[3,4]$ nie podaje się ani zależności na łączny moment od sił bezwładności w ruchu postępowo-zwrotnym, ani jego maksymalnej wartości, lecz tylko amplitudy momentu od sił bezwładności pierwszego i drugiego rzędu. Takie podejście jest słuszne dla mechanizmów korbowych, których parametr $\lambda$ nie przekracza pewnej wartości zależnej od liczby cylindrów. Tymczasem od ponad 25 lat są stosowane w okrętownictwie tzw. silniki długoskokowe o wartości $\lambda$ bliskiej 0,5 .

Celem niniejszej pracy było zbadanie, czy wymieniona prosta metoda doboru optymalnej konfiguracji wału korbowego jest słuszna także dla dość często stosowanego w okrętownictwie silnika 6-cylindrowego, zwłaszcza o dużej wartości i ewentualne określenie granicznej wartość $\lambda$, powyżej której metoda ta traci swoją ważność. Warto zauważyć w tym kontekście, jak wykazano w pracy [1], że dla silników 2-suwowych czterocylindrowych wartość graniczna parametru $\lambda$, powyżej której ten prosty schemat graficzny traci swoją ważność, stanowi liczba 0,527.

Pożyteczna może być także wiedza o tym, jak dalece kolejne konfiguracje odbiegają od najlepszej pod względem wielkości momentu od sił bezwładności w ruchu postępowozwrotnym. W przypadku silników doładowanych w systemie pulsacyjnym zachodzi bowiem niekiedy potrzeba rezygnacji z najlepszego wyrównoważenia na rzecz lepszego doładowania. Równie interesujące może być porównanie poszczególnych konfiguracji wału korbowego po 50-procentowym wyrównoważeniu składowej momentu od sił bezwładności pierwszego rzędu za pomocą przeciwmas umieszczonych na wale korbowym.

\section{Zależności opisujące przebiegi momentu od sil bezwladności pierwszego i drugiego rzędu w silniku 6-cylindrowym}

W silniku 6-cylindrowym obydwa wektory wypadkowe zarówno sił bezwładności w ruchu postępowo-zwrotnym, jak i obrotowym są wektorami zerowymi. Pozostają natomiast niewyrównoważone wektory momentów od tych sił.

Posługując się metodą wektorów fikcyjnych przedstawioną w pracy [2] i uszczegółowioną w [1], można w prosty sposób wyprowadzić zależności na sumy momentów od sił bezwładności pierwszego i drugiego rzędu dla poszczególnych konfiguracji wału korbowego. Jako punkt odniesienia do analizy momentów od sił bezwładności przyjęto punkt przecięcia się osi pierwszego cylindra z osią obrotu wału korbowego oraz jednakową odległość pomiędzy osiami cylindrów.

Przy tych założeniach wartości modułów wektorów fikcyjnych momentów sił bezwładności pierwszego i drugiego rzędu odniesionych odpowiednio do $m_{p} R \omega^{2} a$ i $m_{p} R \omega^{2} \lambda a$ wyrażają zależności (1) i (2), 


$$
\begin{gathered}
\sum_{1}^{6} \mathrm{~B}_{\mathrm{bj}}^{\prime}=\Psi^{\prime} \cos \left[\alpha-90^{\circ}+\varphi^{\prime}\right] \\
\sum_{1}^{6} \mathrm{~B}_{\mathrm{bj}}^{\prime \prime}=\Psi^{\prime \prime \prime} \lambda \cos 2\left(\alpha-90^{\circ}+\varphi^{\prime \prime}\right)
\end{gathered}
$$

where: $\mathrm{j}$ - cylinder number, $\omega$ - crankshaft rotational speed, $\mathrm{m}_{\mathrm{p}}$ - equivalent reciprocating mass, $\mathrm{R}$ - crankshaft throw, $\alpha$-distance between cylinder axis, $\lambda$ - crank throw to connecting rod length ratio, $\Psi^{\prime}$ and $\Psi "$ - amplitude coefficients of fictitious vectors of the primary and secondary moments respectively, $\varphi^{\prime}$ and $\varphi^{\prime \prime}$ - angles determining the directions of fictitious vectors of primary and secondary moments respectively.

The angle $90^{\circ}$ in relations (3) and (4) results from the assumption of the beginning of the crankshaft rotation in the point corresponding to TDC of the first cylinder that is when its crank is in line with the axis $y$, which coincides with cylinder axes, and not $\mathrm{x}$.

\section{Mathematical relations describing moment of inertia forces in reciprocating motion by using two crankshaft configurations as examples}

\subsection{The crankshaft with configuration 1-4-2-6-3-5}

The configuration 1-4-2-6-3-5 has not been chosen by chance. It follows from further part of this paper that the secondary moments of inertia forces for this particular configuration are fully balanced. In order to determine the parameters $\Psi$ ' and $\varphi$ ' for this crankshaft configuration a ,star" of the fictitious vectors $\mathbf{W}_{j}^{\prime}$ for the primary inertia forces $\mathbf{P}^{\prime}{ }_{\mathbf{b j}}$ are presented in Fig. 1a and a polygon of the fictitious vectors of the primary moments in Fig. 1b. The numerical symbols in Fig. 1a from 1 to 5 denote the relative position of the cranks on the crankshaft, in other words the so called "star" of the crank throws while the numerical subscripts denote assigning of a parameter to the given cylinder. It is hard not to notice that the ,star" of the fictitious vectors of inertia forces is the same as the ,star" of the cranks throws. This is the case in each engine irrespective of the engine type and the number of cylinders.

One can easily determine the amplitude coefficient $\Psi^{\prime}$ and angle $\varphi^{\prime}$ of the resultant vector of the moments of the fictitious inertia forces as well as its angle of inclination $\gamma^{\prime}$ to axis $\mathrm{x}$ as a result of assigning the lengths to the vectors of the fictitious moments corresponding to numbers $\mathrm{j}-1$, according to relation (1). Numerical values of the above parameters, determined on the grounds of Fig. $1 \mathrm{~b}$, are the following: a wypadkowych momentów (rzeczywistych) pierwszego i drugiego rzędu odpowiednio zależności (3) i (4), gdzie: $\mathrm{j}$ - numer cylindra, $\omega$ - prędkość kątowa wału korbowego, $\mathrm{m}_{\mathrm{p}}$ - masa $\mathrm{w}$ ruchu postępowo-zwrotnym, $\mathrm{R}$ - promień wykorbienia, a - odległość pomiędzy osiami cylindrów, $\lambda-$ parametr mechanizmu korbowego, $\Psi^{\prime}$ i $\Psi^{\prime \prime}$ - współczynniki amplitud wektorów fikcyjnych momentów odpowiednio pierwszego i drugiego rzędu, $\varphi^{\prime}$ i $\varphi^{\prime \prime}$ - kąty położenia wektorów fikcyjnych momentów odpowiednio pierwszego i drugiego rzędu.

Kąt $90^{\circ} \mathrm{w}$ zależnościach (3) i (4) wynika z przyjęcia początku obrotu wału korbowego w punkcie odpowiadającym GMP pierwszego cylindra, czyli gdy wykorbienie tego cylindra pokrywa się z osią y, która leży na osi cylindra, a nie osią $\mathrm{x}$.

\section{Zależności opisujące przebieg momentu od sil bezwladności w ruchu postępowo-zwrotnym na przykładzie dwóch konfiguracji}

\subsection{Wal korbowy o konfiguracji 1-4-2-6-3-5}

Konfiguracja 1-4-2-6-3-5 nie została wybrana do analizy przypadkowo. Jak się okaże w dalszej części, równoważą się dla niej momenty od sił bezwładności drugiego rzędu. W celu wyznaczenia dla tej konfiguracji wału parametrów

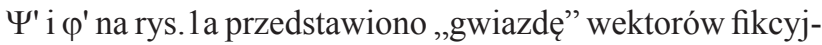
nych $\mathbf{W}_{j}^{\prime}$ dla sił bezwładności pierwszego rzędu $\mathbf{P}^{\prime}{ }^{\prime} \mathbf{j}$, a na rys. $1 \mathrm{~b}$-wielobok wektorów momentów od tych wektorów fikcyjnych. Symbole cyfrowe od 1 do 5 na rys. 1a oznaczają względne usytuowanie wykorbień na wale korbowym, czyli tzw. ,gwiazdę" promieni korb, natomiast indeksy cyfrowe - dolne przyporządkowanie parametru do danego cylindra. Można zauważyć, że ,gwiazda” wektorów sił bezwładności pierwszego rzędu pokrywa się z ,gwiazdą" promieni korb. Tak jest w każdym silniku, niezależnie od rodzaju silnika i liczby cylindrów.

W wyniku przyporządkowania wektorom momentu od sił fikcyjnych poszczególnych cylindrów długości odpowiadających liczbom j-1, zgodnie z zależnością (1), można

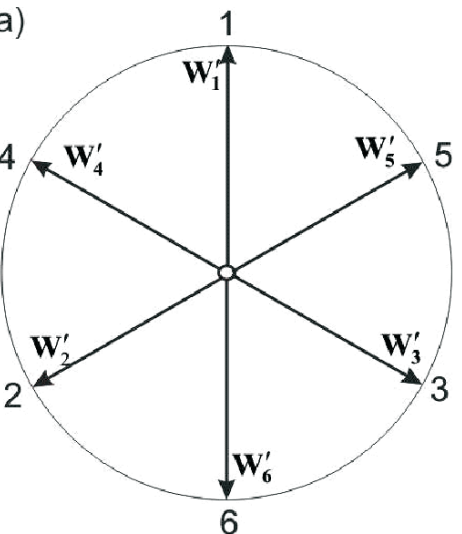

b)

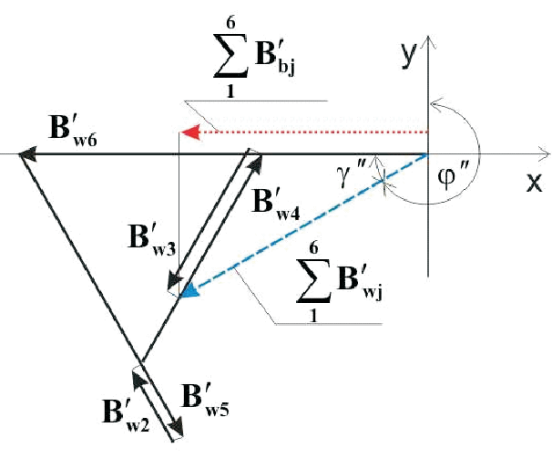

Fig. 1. „Star” of the fictitious first order inertia forces and a polygon of their moments for the crank gear with arrangement of cranks 1-5-3-4-2-6: a) the "star" of fictitious vectors of the first order inertia forces, b) polygon of the fictitious vectors of the moments of the first order inertia forces

Rys. 1. „Gwiazda” wektorów fikcyjnych dla sit bezwładności pierwszego rzędu oraz wielobok fikcyjnych wektorów momentów od tych sił dla konfiguracji wału korbowego 1-4-2-6-3-5: a) „gwiazda” wektorów fikcyjnych pierwszego rzędu, b) wielobok fikcyjnych wektorów momentów od sit bezwładności pierwszego $r z e ̨ d u$ 


$$
\Psi^{\prime}=\sum_{1}^{6} B_{w j}^{\prime}=2 \sqrt{2}, \gamma^{\prime}=30^{0}, \varphi^{\prime}=270^{0}-\gamma^{\prime}
$$

After substituting the values of the parameters $\Psi^{\prime}$ and $\varphi^{\prime}$ to relation (3) we will get the following equation describing the resultant moment of the primary inertia forces in reciprocating motion in the function of crankshaft rotation angle for the analyzed arrangement of the cranks.

$$
\sum_{1}^{6} B_{b j}^{\prime}=-2 \sqrt{2} \cos \left(\alpha-30^{\circ}\right)
$$

bardzo łatwo wyznaczyć współczynnik amplitudy $\Psi$ ' oraz kąt $\varphi^{\prime}$ położenia fikcyjnego wektora momentu wypadkowego na podstawie zależności geometrycznych $\mathrm{w}$ wieloboku momentów, a także kąt $\gamma^{\prime}$, jaki tworzy ten wektor z osią x. Wartości wymienionych parametrów, określone na podstawie rys. $1 \mathrm{~b}$, są następujące:

$$
\Psi^{\prime}=\sum_{1}^{6} \mathrm{~B}_{\mathrm{wj}}^{\prime}=2 \sqrt{2}, \gamma^{\prime}=30^{0}, \varphi^{\prime}=270^{0}-\gamma^{\prime}
$$

Po podstawieniu wartości parametrów $\Psi$ ' i $\varphi^{\prime}$ do zależności (3) otrzymamy wzór (5) na moment wypadkowy od
In order to partly balance the maximum value of the moment expressed by equation (5), which can be reduced to the minimum by $50 \%$, a pair of counterweights must be attached to the crankshaft in the plane going through the axis of its rotation and inclined $30^{\circ}$ to the crank of the first cylinder in the direction opposite to the crankshaft rotation.

The equation for the moment of the secondary inertia forces can be determined in a similar way. In order to do this a "star" of the fictitious vectors of the secondary inertia forces and a polygon of their moments are presented in Fig. 2.

The polygon in Fig. $2 b$ shows a)

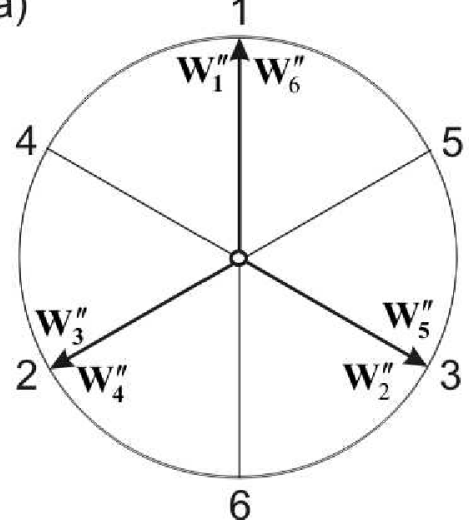

b)

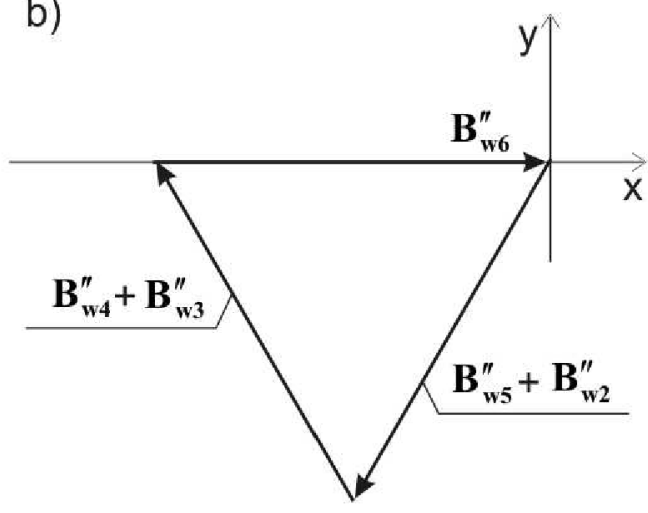

Fig. 2. "Star" of fictitious vectors of the second order inertia forces and a polygon of the vectors of their moments in the crank gear with arrangement of cranks 1-4-2-6-3-5: a) the "star" of the fictitious vectors of the second order inertia forces, b) the polygon of the fictitious vectors of the moments of the second order inertia forces

Rys. 2. „Gwiazda” wektorów fikcyjnych dla sił bezwładności drugiego rzędu oraz wielobok momentów od tych sił dla konfiguracji wału korbowego 1-4-2-6-3-5: a) „, gwiazda” wektorów fikcyjnych drugiego rzędu, b) wielobok momentów od wektorów fikcyjnych sił bezwładności drugiego rzędu of the secondary inertia forces is a zero vector. It means that the relative value of the maximum moment of the inertia forces in reciprocating motion for the engine with the crankshaft configuration 1-4-2-6-3-5 equals the amplitude coefficient of the resultant moment of the primary inertia forces as below

$$
\left(\sum_{1}^{6} \mathrm{~B}_{\mathrm{bj}}^{\prime}\right)_{\max }=\Psi^{\prime}=2 \sqrt{2}
$$

That being so, the moment of inertia forces in reciprocating motion in a six-cylinder engine with the crankshaft configuration 1-4-2-6-3-5 does not depend on the value of parameter $\lambda$ and can be expressed by equation (5).

\subsection{The crankshaft with configuration 1-5-3-4-2-6}

The crankshaft configuration 1-5-3-4-2-6 has the best arrangement of cranks in terms of the resultant moment of the primary inertia forces in reciprocating motion as well as the moment of the centrifugal forces. A "star" of fictitious vectors $\mathbf{W}_{j}$ is presented in Fig. 3a and in Fig. $3 \mathrm{~b}$ - a polygon of the vectors of the moments of the inertia forces. sił bezwładności pierwszego rzędu $\mathrm{w}$ ruchu postępowozwrotnym, w funkcji kąta obrotu wału korbowego, dla analizowanej konfiguracji wału korbowego.

W celu częściowego zredukowania wartości momentu wyrażonego zależnością (5), który można maksymalnie zmniejszyć o połowę, należy umieścić parę przeciwmas w płaszczyźnie przechodzącej przez oś obrotu wału korbowego i opóźniającej się za wykorbieniem pierwszego cylindra o kąt $30^{\circ}$.

W podobny sposób można wyznaczyć wyrażenie na moment od sił bezwładności drugiego rzędu. W tym celu na rysunku 2 przedstawiono gwiazdę wektorów fikcyjnych dla sił bezwładności drugiego rzędu oraz wielobok wektorów momentów od tych sił.

Jak wynika $\mathrm{z}$ wieloboku momentów na rys. $2 \mathrm{~b}$ wektor fikcyjny wypadkowego momentu od sił bezwładności drugiego rzędu jest wektorem zerowym. Oznacza to, że względna wartość maksymalnego momentu od sił bezwładności w ruchu postępowo-zwrotnym dla silnika o konfiguracji wału korbowego 1-4-2-6-3-5 jest równa amplitudzie wypadkowego momentu od sił bezwładności pierwszego rzędu i wynosi: 
a)

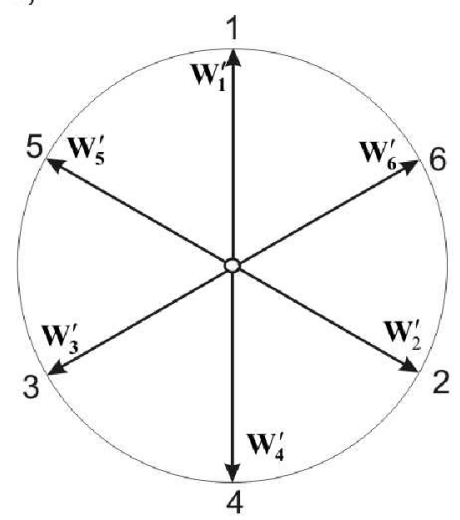

Fig. 3. "Star" of the fictitious first order inertia forces and a polygon of their moments for the crank gear with arrangement of cranks 1-5-3-4-2-6: a) the "star" of fictitious vectors of the first order inertia forces, b) polygon of the fictitious vectors of moments of the first order inertia forces

Rys. 3. „, Gwiazda” wektorów fikcyjnych dla sił bezwładności pierwszego rzędu oraz wielobok wektorów momentów od tych sit dla konfiguracji wału korbowego 1-5-3-4-2-6: a) , gwiazda” wektorów fikcyjnych pierwszego rzędu, b) wielobok wektorów fikcyjnych momentów od sił bezwładności pierw-

It follows from Fig. 3 that the resultant vector of the moments of the primary fictitious forces is a zero vector. This entails that the resultant vector of the moments of the actual primary inertia forces for this arrangement of cranks is a zero vector as well. So the moments of the primary inertia forces are not transmitted outside of the engine and do not load the bolts fastening the engine to its foundation.

A system of the fictitious vectors $\mathbf{W}^{\prime \prime}$, for the secondary inertia forces is presented in Fig. $4 \mathrm{a}$ and a polygon of their moments in Fig. 4b.

In the right-angled triangle, whose sides are the resultant vectors of the moments $\sum_{1}^{6} \mathbf{B}_{\mathrm{wj}}^{\prime \prime}$ and $\sum_{1}^{6} \mathbf{B}_{\mathrm{bj}}^{\prime \prime}$ of the fictitious and actual secondary forces respectively and angle $\gamma^{\prime \prime}$ between them it is very easy to determine the lengths of its sides which amount to $\sqrt{2}$ and 3 and then calculate $\Psi ", \gamma^{\prime \prime}$ and $\varphi$ ". Consequently we get the following values of the above parameters:

$$
\begin{aligned}
& \Psi^{\prime \prime}=2 \sqrt{3}, \gamma^{\prime \prime}=30^{0} \\
& \varphi^{\prime \prime}=270-\frac{\gamma^{\prime \prime}}{2}=255^{0}
\end{aligned}
$$

Replacing angle $\gamma^{\prime \prime}$ with $\gamma^{\prime \prime} / 2$ in relation for $\varphi$ " results from the fact that the resultant vector of the fictitious moments of the secondary inertia forces rotates at a speed twice that of the crankshaft. In this case after the turn

b)

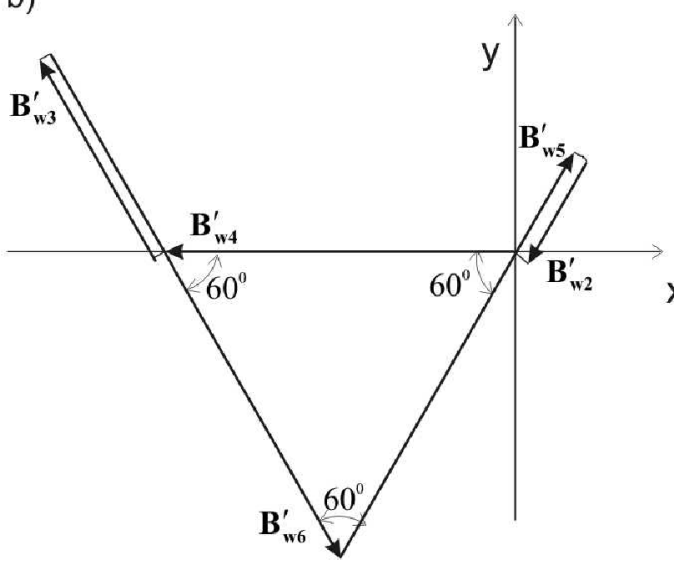
szego rzędu a)

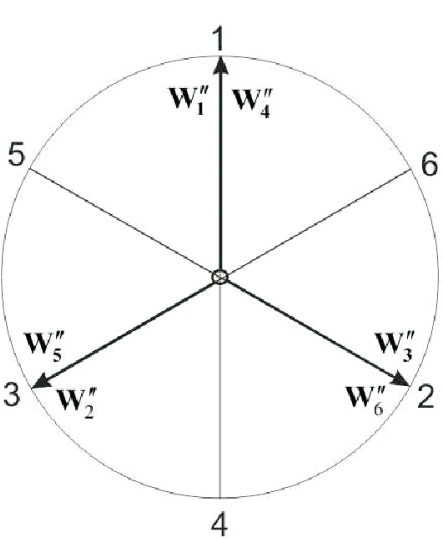

$$
\left(\sum_{1}^{6} \mathrm{~B}_{\mathrm{bj}}^{\prime}\right)_{\max }=\Psi^{\prime}=2 \sqrt{2}
$$

Wobec powyższego przebieg momentu od sił bezwładności w ruchu postępowo-zwrotnym w silniku spalinowym 6-cylindrowym $\mathrm{z}$ wałem korbowym o konfiguracji 1-4-2-6-3-5 jest niezależny od wartości parametru mechanizmu korbowego $\lambda \mathrm{i}$ jest wyrażony zależnością (5).

\subsection{Wal korbowy o konfiguracji}

1-5-3-4-2-6

Wał korbowy o konfiguracji 1-5-3-4-2-6 ma najlepsze względne usytuowanie wykorbień na wale korbowym, z punktu widzenia wypadkowego momentu od sił bezwładności pierwszego rzędu oraz momentu od sił bezwładności w ruchu obrotowym. Na rysunku 3a przedstawiono „gwiazdę" wektorów fikcyjnych $\mathbf{W}_{\mathrm{j}}^{\prime}$, a na rys. $3 \mathrm{~b}$ - wielobok wektorów momentów od tych sił.

Jak wynika z rysunku 3, wypadkowy wektor momentu od sił fikcyjnych pierwszego rzędu jest wektorem zerowym, co jest równoznaczne $\mathrm{z}$ tym, że suma momentów od sił bezwładności pierwszego rzędu dla tej konfiguracji wału korbowego jest także wektorem zerowym. A więc momenty od sił bezwładności pierwszego rzędu nie przenoszą się na zewnątrz silnika i nie obciążają śrub mocujących go do fundamentu.

Na rysunku 4a przedstawiono układ wektorów fikcyjnych drugiego rzędu $\mathbf{W}^{\text {j, }}$, a na rys. 4b wielobok momentów od tych wektorów.

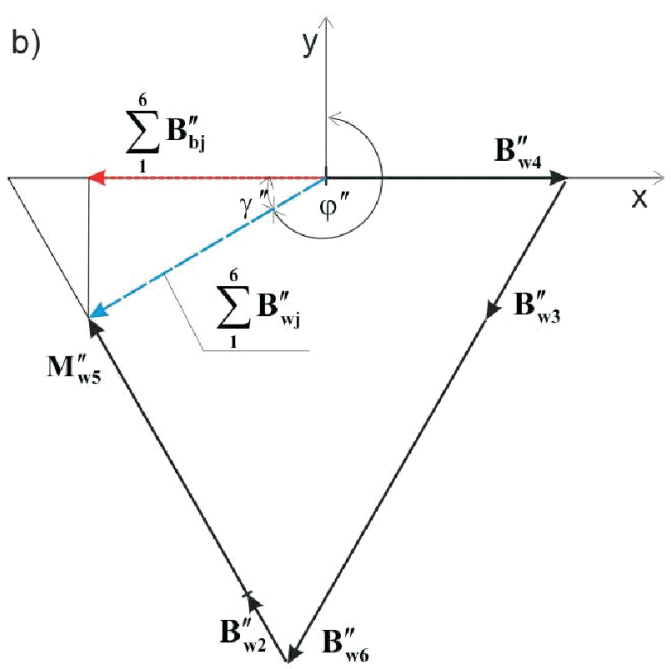

Fig. 4. "Star" of the fictitious vectors of the second order inertia forces and a polygon of the vectors of their moments in the crank gear with the arrangement of cranks 1-5-3-4-2-6: a) the "star" of the fictitious vectors of the second order inertia forces, b) the polygon of the fictitious vectors of the moments of the second order inertia forces

Rys. 4. „, Gwiazda” wektorów fikcyjnych dla sił bezwładności drugiego rzędu oraz wielobok momentów od tych sił dla konfiguracji watu korbowego 1-5-3-4-2-6: a) „,gwiazda” wektorów fikcyjnych drugiego rzędu. b) wielobok wektorów fikcyjnych momentów od sił bezwładności drugiego rzędu 
of the crankshaft by $\gamma^{\prime \prime} / 2$ the resultant vector of the fictitious moments will turn by the angle $\gamma^{\prime \prime}$.

After substituting the $\Psi "$ and $\varphi$ " values to relation (4) we will get the following form of the equation describing the sum of the moments of the secondary inertia forces.

$$
\sum_{1}^{6} \mathrm{~B}_{\mathrm{bj}}^{\prime \prime}=-2 \sqrt{3} \lambda \cos \left(\alpha-15^{0}\right)
$$

On account of the fact that the moments of the primary inertia forces are mutually balanced relation (7) describes simultaneously the combined resultant moment of the primary and secondary inertia forces. That being so the maximum value of the relative moment of inertia forces in reciprocating motion equals the amplitude coefficient of the secondary inertia forces multiplied by parameter $\lambda$ and amounts to:

$$
\left(\sum_{1}^{6} \mathrm{M}_{\mathrm{bj}}\right)_{\max }=\left(\sum_{1}^{6} \mathrm{M}_{\mathrm{bj}}^{\prime \prime}\right)_{\max }=\Psi^{\prime \prime} \lambda=2 \sqrt{3} \lambda
$$

The values of the amplitude coefficients $\Psi$ ' and $\Psi "$ and angles $\gamma^{\prime}$ and $\gamma^{\prime \prime}$ as well as $\varphi^{\prime}$ and $\varphi^{\prime \prime}$ for the remaining fifty eight crankshaft's configurations can be calculated in a similar way.

\section{Analysis of IC engine balancing with different crankshaft configurations}

As mentioned in the introduction, for a six cylinder engine there is a possibility to design a crankshaft with the cranks arranged in 60 different ways. These crankshaft configurations are incorporated in Table 1.

The values of the amplitude coefficients $\Psi^{\prime}$ and $\Psi "$ as well as angles $\varphi^{\prime}$ and $\varphi^{\prime \prime}$ calculated according to the method presented in charter 3 , for all 60 theoretically possible configurations of the crankshaft, are included in [5]. This makes it possible to mathematically describe the resultant moment of the inertia forces in reciprocating motion for each of the 60 crankshaft configurations. In order not to increase the volume of this paper Table 2 includes the values of the calculated parameters for 10 chosen configurations, including the best 9, and the worst one which is denoted by No. 10 .
W trójkącie prostokątnym, którego bokami są wektory wypadkowe momentów od sił fikcyjnych drugiego rzędu $\sum_{1}^{6} \mathbf{B}_{\mathrm{wj}}^{\prime \prime} \mathrm{i} \sum_{1}^{6} \mathbf{B}_{\mathrm{bj}}^{\prime \prime}$ rzeczywistych oraz kąt $\gamma^{\prime \prime}$ między nimi łatwo można określić długości jego przyprostokątnych, które wynoszą $\sqrt{2}$ i 3 , a następnie obliczyć $\Psi$ ", $\gamma^{\prime \prime}$ i $\varphi^{\prime \prime}$. W efekcie otrzymuje się wartości poszukiwanych parametrów - wzór (6).

Wstawianie kąta $\gamma^{\prime \prime} / 2$, a nie $\gamma^{\prime \prime}$, do zależności na $\varphi^{\prime \prime}$ wynika stąd, że wektor fikcyjny wypadkowego momentu sił bezwładności drugiego rzędu wiruje z prędkością kątową dwa razy większą niż wał korbowy. Wobec tego po obrocie wału korbowego o kąt $\gamma^{\prime \prime} / 2$ wektor fikcyjny wypadkowego momentu obróci się o kąt $\gamma^{\prime \prime}$.

Po podstawieniu wartości $\Psi$ " i $\varphi$ " do zależności (4) otrzymamy następującą postać równania na sumę momentów od sił bezwładności drugiego rzędu - wzór (7).

Z uwagi na to, że momenty od sił bezwładności pierwszego rzędu równoważą się wzajemnie, zależność (7) opisuje jednocześnie przebieg łącznego wypadkowego momentu od sił bezwładności w ruchu postępowo-zwrotnym. Wobec powyższego wartość maksymalna względnej wartości momentu od sił bezwładności w ruchu postępowo-zwrotnym jest równa współczynnikowi amplitudy momentu od sił bezwładności drugiego rzędu pomnożonemu przez parametr $\lambda$ i wynosi (8).

W podobny sposób można obliczyć wartości współczynników amplitudowych $\Psi^{\prime}$ i $\Psi "$, kątów $\gamma^{\prime}$ i $\gamma^{\prime \prime}$ oraz $\varphi^{\prime}$ i $\varphi^{\prime \prime}$ dla pozostałych 58 konfiguracji wału korbowego.

\section{Analiza wyrównoważenia silnika o różnych konfiguracjach wału korbowego}

Jak wspomniano we wstępie, dla silnika 6-cylindrowego istnieje możliwość zaprojektowania wału korbowego, w którym wykorbienia mogą być ustawione sześćdziesięcioma różnymi sposobami. Te konfiguracje wału zawiera tab. 1.

Wartości współczynników amplitudowych $\Psi^{\prime}$ i $\Psi "$ oraz kątów $\varphi^{\prime}$ i $\varphi^{\prime \prime}$ położenia fikcyjnych wektorów momentów wypadkowych, obliczone zgodnie z metodyką przedstawioną w punkcie 3, dla wszystkich 60 teoretycznie możliwych konfiguracji wału korbowego zostały zawarte w pracy [5].

Table 1. Denotations of all configurations of the crankshaft

Tabela 1. Oznaczenia wszystkich konfiguracji watu korbowego

\begin{tabular}{|c|c|c|c|c|c|c|c|c|c|c|c|}
\hline No. & Configuration & No. & Configuration & No. & Configuration & No. & Configuration & No. & Configuration & No. & Configuration \\
\hline 1 & 123456 & 11 & 124635 & 21 & 126435 & 31 & 134256 & 41 & 136425 & 51 & 145236 \\
\hline 2 & 123465 & 12 & 124653 & 22 & 126453 & 32 & 134265 & 42 & 136524 & 52 & 145326 \\
\hline 3 & 123546 & 13 & 125346 & 23 & 126534 & 33 & 134526 & 43 & 142356 & 53 & 146235 \\
\hline 4 & 123564 & 14 & 125364 & 24 & 126543 & 34 & 134625 & 44 & 142365 & 54 & 146325 \\
\hline 5 & 123654 & 15 & 125436 & 25 & 132456 & 35 & 135246 & 45 & 142536 & 55 & 152346 \\
\hline 6 & 123645 & 16 & 125463 & 26 & 132465 & 36 & 135264 & 46 & 142635 & 56 & 152436 \\
\hline 7 & 124356 & 17 & 125634 & 27 & 132546 & 37 & 135426 & 47 & 143256 & 57 & 153246 \\
\hline 8 & 124365 & 18 & 125643 & 28 & 132564 & 38 & 135624 & 48 & 143265 & 58 & 153426 \\
\hline 9 & 124536 & 19 & 126345 & 29 & 132654 & 39 & 136245 & 49 & 143526 & 59 & 154236 \\
\hline 10 & 124563 & 20 & 126354 & 30 & 132645 & 40 & 136254 & 50 & 143625 & 60 & 154326 \\
\hline
\end{tabular}


Table 2. The values of the amplitude coefficients and the position angles of the fictitious vectors of the resultant moments of the first and second order inertia forces

Tabela 2. Wartości współczynników amplitud oraz kątów położenia fikcyjnych wektorów momentów wypadkowych sił bezwładności pierwszego i drugiego rzędu

\begin{tabular}{|c|c|c|c|c|c|c|c|}
\hline \multirow{2}{*}{ No } & \multirow{2}{*}{ Configuration } & \multicolumn{2}{|c|}{ Amplitude coefficient } & \multicolumn{4}{|c|}{ Angles of the resultant vector position } \\
\cline { 3 - 8 } & $\Psi^{\prime}[-]$ & $\Psi^{\prime \prime}[-]$ & $\gamma^{\prime}\left[{ }^{\circ}\right]$ & $\varphi^{\prime}\left[{ }^{\circ}\right]$ & \multicolumn{2}{c|}{$\gamma^{\prime \prime}\left[{ }^{\circ}\right]$} & $\varphi^{\prime \prime}\left[{ }^{\circ}\right]$ \\
\hline 10 & 124563 & 7 & $\sqrt{3}$ & 27,79 & $270-\gamma^{\prime}$ & 30 & $270+\gamma^{\prime \prime} / 2$ \\
\hline 45 & 142536 & 3 & $\sqrt{3}$ & 60 & $270-\gamma^{\prime}$ & 30 & $270-\gamma^{\prime \prime} / 2$ \\
\hline 46 & 142635 & $2 \sqrt{3}$ & 0 & 30 & $270-\gamma^{\prime}$ & - & $270-\gamma^{\prime \prime} / 2$ \\
\hline 49 & 143526 & $\sqrt{3}$ & 3 & 30 & $270-\gamma^{\prime}$ & 30 & $270-\gamma^{\prime \prime} / 2$ \\
\hline 50 & 143625 & 3 & $\sqrt{3}$ & 0 & $270-\gamma^{\prime}$ & 90 & $270-\gamma^{\prime \prime} / 2$ \\
\hline 51 & 145236 & 0 & $4 \sqrt{3}$ & - & $270-\gamma^{\prime}$ & 30 & $270-\gamma^{\prime \prime} / 2$ \\
\hline 52 & 145326 & 1 & $\sqrt{39}$ & 60 & $270+\gamma^{\prime}$ & 43,9 & $270-\gamma^{\prime \prime} / 2$ \\
\hline 56 & 152426 & $\sqrt{3}$ & 3 & 90 & $270-\gamma^{\prime}$ & 0 & $270-\gamma^{\prime \prime} / 2$ \\
\hline 58 & 153426 & 0 & $2 \sqrt{3}$ & - & $270-\gamma^{\prime}$ & & 30 \\
\hline 60 & 154236 & 1 & $3 \sqrt{3}$ & 60 & $270-\gamma^{\prime}$ & 30 & $270-\gamma^{\prime \prime} / 2$ \\
\hline
\end{tabular}

Table 3. Maximum and minimum values and the range of change of the amplitude coefficients of the moments of the inertia forces of the reciprocating masses for $\lambda=0.3$ and 0.5

Tabela 3. Wartości maksymalne, minimalne i zakres zmian wspótczynnika momentu od sił bezwładności mas w ruchu postępowo-zwrotnym dla $\lambda=0,3$ i 0,5

\begin{tabular}{|c|c|c|c|c|c|c|c|}
\hline \multirow{3}{*}{ No } & \multirow{3}{*}{ Configuration } & \multicolumn{6}{|c|}{$\sum_{1}^{6} B_{b j}$} \\
\hline & & \multicolumn{3}{|c|}{$\lambda=0.3$} & \multicolumn{3}{|c|}{$\lambda=0.5$} \\
\hline & & Maximum & Minimum & Range of change & Maximum & Minimum & Range of change \\
\hline 10 & 124563 & 6,501 & $-7,508$ & 14,01 & 6,180 & $-7,850$ & 14,03 \\
\hline 45 & 142536 & 3,159 & $-3,159$ & 6,319 & 3,385 & $-3,385$ & 6,769 \\
\hline 46 & 142635 & 3,464 & $-3,464$ & 6,928 & 3,484 & $-3,464$ & 6,928 \\
\hline 49 & 143526 & 1,692 & $-2,592$ & 4,284 & 2,165 & $-3,186$ & 5,351 \\
\hline 50 & 143625 & 3,159 & $-3,159$ & 6,319 & 3,385 & $-3,385$ & 6,769 \\
\hline 51 & 145236 & 2,078 & $-2,078$ & 4,157 & 3,464 & $-3,464$ & 6,928 \\
\hline 52 & 145326 & 2,528 & $-2,684$ & 5,212 & 3,762 & $-3,924$ & 7,687 \\
\hline 56 & 152426 & 2,627 & $-1,458$ & 4,085 & 3,226 & $-1,905$ & 5,131 \\
\hline 58 & 153426 & 1,039 & $-1,039$ & 2,078 & 1,732 & $-1,732$ & 3,464 \\
\hline 60 & 154236 & 2,302 & $-2,302$ & 4,604 & 3,328 & $-3,328$ & 6,655 \\
\hline
\end{tabular}

The equations describing the moments of the inertia forces derived on the basis of the data included in Table 2 were used to calculate the absolute extremums of functions (minima and maxima) as well as the range of the maximum changes of the moments for 10 crankshaft configurations included in Table 3 . The results of the calculations are presented in Table 3.

In order to illustrate the results obtained they are illustrated graphically in the form of a bar chart in Fig. 5. It follows from the figure, which concerns the crank gears with $\lambda=0.3$, that the configuration 58 is characterized by far the smallest value of the maximum moment of the inertia forces
Umożliwiają one opis matematyczny przebiegu momentów wypadkowych od sił bezwładności w ruchu postępowozwrotnym dla każdej z 60. konfiguracji wału korbowego. Aby nie powiększać objętości niniejszego artykułu, w tab. 2 zamieszczono wartości obliczonych parametrów dla 10 wybranych konfiguracji, w tym dla 9 najlepszych oraz jednej najgorszej, która jest oznaczona nr 10 .

Równania opisujące przebieg momentu od sił bezwładności, opracowane na podstawie danych zawartych w tab. 2 , posłużyły do obliczenia bezwzględnych ekstremów funkcji (minimum i maksimum), a także zakresów maksymalnych zmian momentu dla 10. zawartych w tej tabeli konfiguracji 


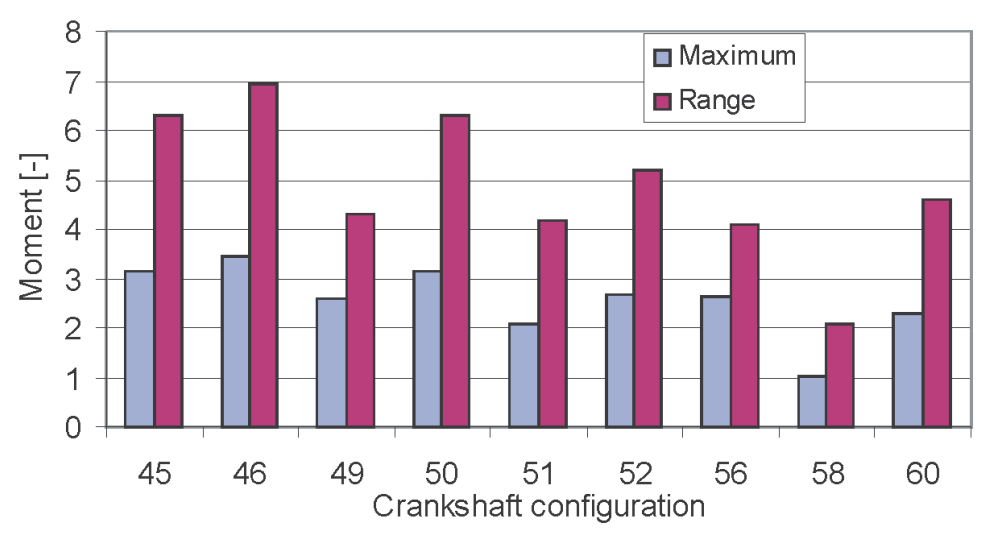

Fig. 5. Bar chart of a relative maximum values of the resultant moment of the inertia forces of the reciprocating masses and the ranges of their change for different arrangements of cranks and $\lambda=0.3$

Rys. 5. Wykres slupkowy maksymalnych względnych wartości oraz zakresu zmian sumy momentów od sił bezwładności w ruchu postępowo-zwrotnym dla poszczególnych konfiguracji watu korbowego, dla $\lambda=0,3$

in reciprocating motion. The range of the moment change for this configuration is also the smallest.

The next three configurations in order 51, 60 and 49 have the absolute maximum values of the moment of the inertia forces in reciprocating motion bigger than configuration 58 by $100 \%, 122 \%$ and $150 \%$ respectively. The plots of the moments of the inertia forces for the best four configurations of the crankshaft are presented in Fig. 6.

The course of the moment for the worst configuration denoted by 10 was also plotted in Fig. 6. For comparison purposes Fig. 7 shows the bar chart of the maximum values of the moment of the inertia forces in reciprocating motion drawn on the grounds of the calculations included in Table 3 , for the same configurations of the crankshaft but for parameter $\lambda=0.5$.

The height of the bars in Fig. 7 indicates that despite some drop in advantage of configuration 58 for $\lambda=0.5$ compared to $\lambda=0.3$ it is still high. Configurations 56, 60 and 49 have in this case relatively big moments of the inertia forces, greater than configuration 58 by $86 \%, 92 \%$ and $95 \%$ respectively. Well then, despite the fact that the differences between the best configuration of the crankshaft and the remaining ones decrease in terms of the engine balance, none of the remaining 59 configurations is an alternative to configuration 58 for the $\lambda$ values used in practice. The plots of the moments versus angle of the crank travel for the four best configurations of the crankshaft and the worst one are presented in Fig. 8.

In the context of the analysis of the moments of the inertia forces the question arises concerning the value of the crank gear parameter $\lambda$ above which the advantage of the configuration 58 over the next best in turn disappears. Analysing the values in table 3 it is hard not to notice, however, that this value wału korbowego. Wyniki obliczeń zostały zamieszczone w tab. 3.

Dla zilustrowania otrzymanych wyników obliczeń przedstawiono je graficznie w formie wykresów słupkowych na rys. 5. Jak wynika z rys. 5, który dotyczy mechanizmów korbowych o wartości parametru $\lambda=0,3$, najmniejszą wartością maksymalnego momentu od sił bezwładności w ruchu postępowo-zwrotnym charakteryzuje się konfiguracja nr 58. Także zakres zmian momentu dla tej konfiguracji wału jest najmniejszy.

Następne trzy w kolejności konfiguracje wału korbowego 51, 60 i 49 mają bezwzględną wartość maksymalnego momentu od sił bezwładności w ruchu postępowo-zwrotnym odpowiednio o 100, 122 i 150\% większą niż konfiguracja 58. Przebiegi momentów od sił bezwładności dla tych czterech konfiguracji wału korbowego przedstawiono graficznie na rys. 6.

$\mathrm{Na}$ wykres naniesiono również przebieg momentu dla najgorszej konfiguracji oznaczonej numerem 10. Dla porównania, na rys. 7 przestawiono wykresy słupkowe maksymalnego momentu od sił bezwładności dla tych samych konfiguracji wału korbowego opracowane na podstawie wyników obliczeń zawartych w tab. 3, ale dla parametru mechanizmu korbowego $\lambda=0,5$.

Wysokość słupków na rys.7 wskazuje, że pomimo pewnego spadku przewagi konfiguracji 58 dla $\lambda=0,5$, w stosunku do jej przewagi dla $\lambda=0,3$, jest ona wciąż wysoka. Konfiguracje 56, 60 i 49 mają również w tym przypadku względnie duże wartości momentu od sił bezwładności, odpowiednio o 86, 92 i 95\% większe niż konfiguracja

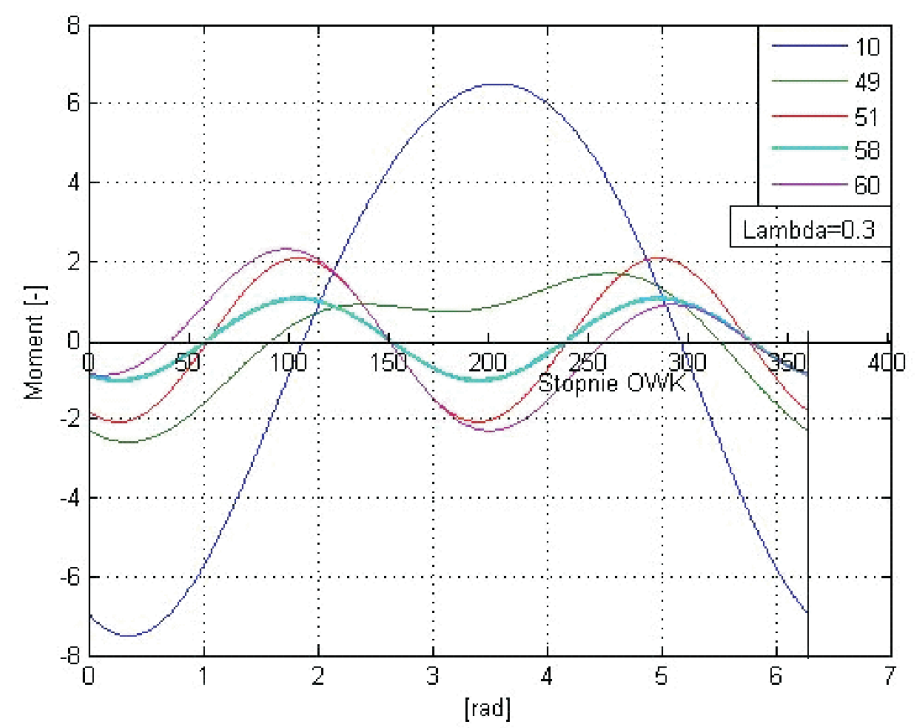

Fig. 6. Influence of the cranks arrangement on the resultant moment of the inertia forces of the reciprocating masses for $\lambda=0.3$

Rys. 6. Wptyw konfiguracji wału korbowego na wypadkowy moment od sit bezwladności mas $w$ ruchu postepowo-zwrotnym dla $\lambda=0,3$ 


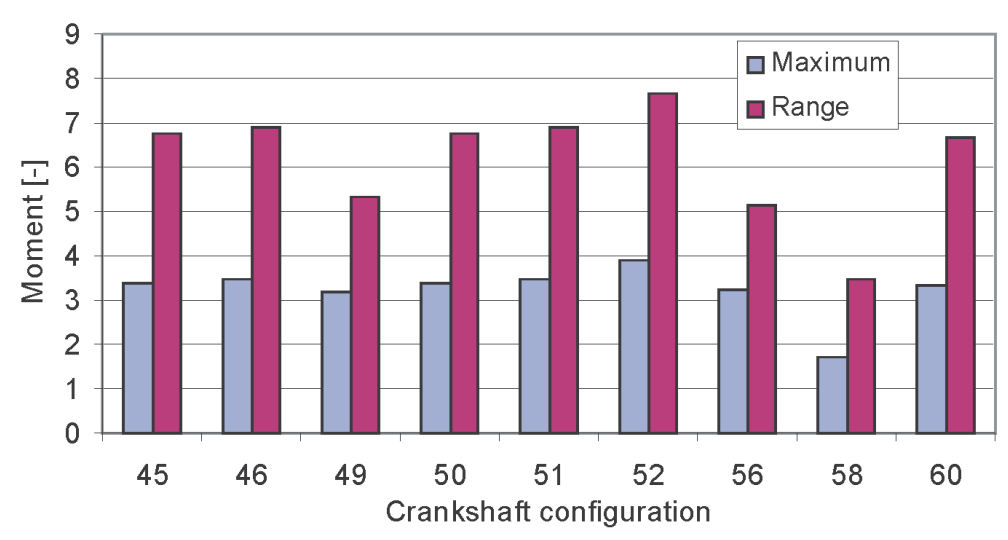

Fig. 7. Bar chart of the relative maximum values of the resultant moment of the inertia forces of the reciprocating masses and the range of their changes for different arrangements of cranks and $\lambda=0.5$

Rys. 7. Wykres stupkowy maksymalnych względnych wartości sumy momentów od sit bezwładności w ruchu postępowo-zwrotnym i zakresów zmian momentu dla poszczególnych konfiguracji watu korbowego, dla $\lambda=0,5$

of $\lambda$ is 1 . For $\lambda=1$ the best configuration 58 equates with 46 with respect to the maximum moment of the inertia forces in reciprocating motion. It is obvious that $\lambda=1$ has only a theoretical meaning because it is over two times bigger than the values used in shipbuilding in the long-stroke engines. Besides, if kinematics of the crank gear is taken into account, the $\lambda$ value must be smaller than one.

\section{A comparison of the crankshaft configurations after $50 \%$ balancing of the primary component of the moment of the inertia forces}

It's a well known fact, that it is possible to balance $50 \%$ of the maximum moment of the primary inertia forces with

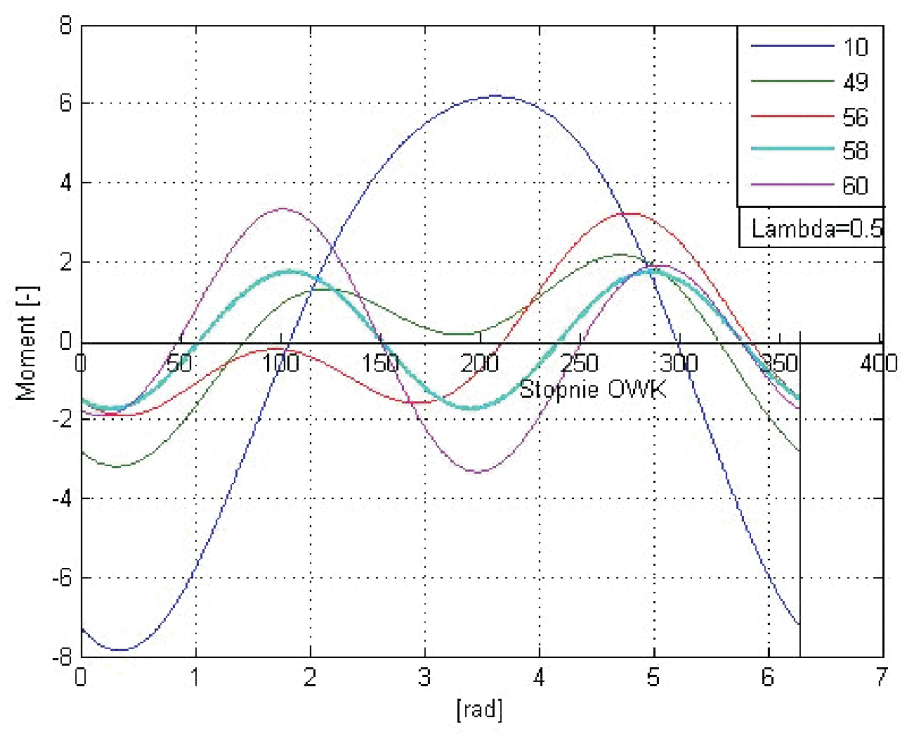

Fig. 8. Influence of the cranks arrangement on the resultant moment of the inertia forces of the reciprocating masses for $\lambda=0.5$

Rys. 8. Wptyw konfiguracji wału korbowego na wypadkowy moment sił bezwładności od mas $w$ ruchu postepowo-zwrotnym dla $\lambda=0,5$
58. Tak więc, mimo że wraz ze wzrostem $\lambda$ zmniejszają się różnice pomiędzy najlepszą a pozostałymi konfiguracjami pod względem wyrównoważenia silnika, to żadna z pozo stałych 59 konfiguracji nie może stanowić alternatywy dla konfiguracji $58 \mathrm{w}$ zakresie wartości parametru $\lambda$ spotykanych w praktyce. Przebiegi momentu w funkcji kąta obrotu wału korbowego dla $\lambda=0,5$, dla czterech najlepszych konfiguracji wału korbowego i jednej najgorszej przedstawiono na rys. 8 .

W kontekście uzyskanych wyników analizy momentów od sił bezwładności rodzi się pytanie o wartość parametru mechanizmu korbowego $\lambda$, dla której znika przewaga konfiguracji 58, nad następną w kolejności. Nietrudno zauważyć, analizując wartości podane w tab. 1, że tę wartość parametru stanowi $\lambda=1$. Dla $\lambda=1$ najlepsza dotychczas konfiguracja 58 zrównuje się pod względem maksymalnego momentu od sił bezwładności w ruchu postępowo-zwrotnym z konfiguracją 46. Oczywiste jest, że $\lambda=1$ ma jedynie teoretyczne znaczenie, gdyż wartość ta jest ponad dwukrotnie większa od największych wartości $\lambda$ spotykanych w okrętownictwie, $w$ tzw. silnikach długoskokowych. Poza tym z punktu widzenia kinematyki mechanizmu korbowego wartość parametru $\lambda$ musi być mniejsza od 1.

\section{Porównanie konfiguracji wału korbowego po 50-procentowym wyrównoważeniu składowej momentu od sil bezwladności pierwszego rzędu}

Wiadomo, że za pomocą przeciwmas umieszczonych na wale korbowym można wyrównoważyć tylko połowę wypadkowego momentu od sił bezwładności pierwszego rzędu. Wobec tego optymalna wartość modułu względnej wartości wektora momentu wyrównoważającego zgodnie z zależnością (3) powinna mieć wartość odpowiadającą połowie współczynnika momentu $\Psi^{\prime} / 2$. Może być zatem interesujące zbadanie wpływu takiego stopnia wyrównoważenia momentu od sił bezwładności pierwszego rzędu na wypadkowy moment od sił bezwładności dla poszczególnych konfiguracji wału korbowego. W celu obliczenia wypadkowego momentu $\mathbf{B}_{\mathbf{5 0}}$ po 50-procentowym wyrównoważeniu składowej pierwszego rzędu, na podstawie zależności (3) i (4), wyprowadzono wzór (9) na długość tego wektora.

Obliczone wartości wektora $\mathbf{B}_{50}$ na podstawie zależności (9), dla dwóch wartości parametru $\lambda=0,3$ i 0,5 , dla 8 . najlepszych konfiguracji wału korbowego zamieszczono w tab. 4.

Jak wynika z tabeli 4 , z punktu widzenia modułu maksymalnej wartości momentu, w 
Table 4. Maximum and minimum values and the range of change of the moments of the inertia forces of the reciprocating masses for $\lambda=0.3$ and 0.5 after $50 \%$ balancing of the moment of the first order inertia forces

Tabela 4. Wartości maksymalne, minimalne i zakres zmian modułu momentu od sił bezwładności $w$ ruchu postępowo-zwrotnym dla $\lambda=0,3 i$ 0,5 w następstwie wyrównoważenia w 50\% składowej pierwszego rzędu

\begin{tabular}{|c|c|c|c|c|c|c|c|}
\hline \multirow{3}{*}{ No. } & \multirow{3}{*}{ Shaft config. } & \multicolumn{6}{|c|}{$\mathbf{B}_{50}$} \\
\hline & & \multicolumn{3}{|c|}{$\lambda=0.3$} & \multicolumn{3}{|c|}{$\lambda=0.5$} \\
\hline & & Minimum & Maximum & Range of changes & Minimum & Maximum & Range of changes \\
\hline 45 & 142536 & 1.131 & 1.923 & 0.791 & 0.929 & 2.223 & 1.295 \\
\hline 46 & 142635 & 1.732 & 1.732 & 0 & 1.732 & 1.732 & 0 \\
\hline 49 & 143526 & 0.062 & 1.753 & 1.690 & 0.181 & 2.349 & 2.168 \\
\hline 50 & 143625 & 1.131 & 1.923 & 0.791 & 0.929 & 2.223 & 1.295 \\
\hline 51 & 145236 & -2.078 & 2.078 & 4.157 & -3.464 & 3.464 & 6.928 \\
\hline 56 & 152426 & 0.017 & 1.764 & 1.747 & 0.324 & 2.364 & 2.039 \\
\hline 58 & 153426 & -.039 & 1.039 & 2.078 & -1.732 & 1.732 & 3.464 \\
\hline 60 & 154236 & 0.0792 & 1.951 & 1.872 & 0.049 & 2.977 & 2.928 \\
\hline
\end{tabular}

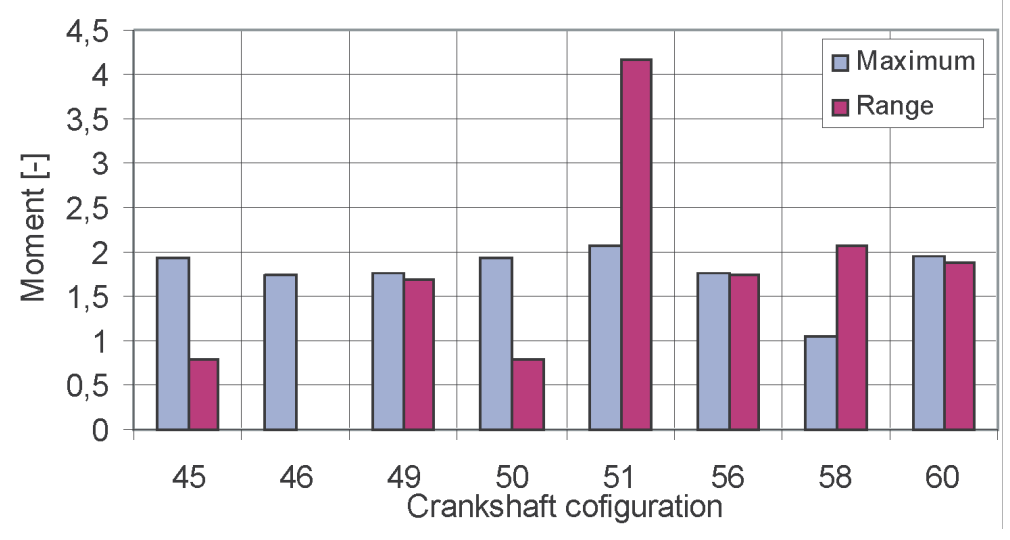

Fig. 9. Bar chart of the relative maximum values of resultant moment $\mathrm{B}_{\mathrm{w}}$ and the range of its change for different arrangements of cranks and $\lambda=0.3$

Rys. 9. Wykres stupkowy maksymalnych względnych wartości wypadkowego momentu $B_{w}$ $i$ zakresu jego zmian dla poszczególnych konfiguracji wału korbowego dla $\lambda=0,3$ dalszym ciągu zdecydowanie najlepsza jest powszechnie stosowana w silnikach 2-S sześciocylindrowych konfiguracja 1-5-3-4-2-6, oznaczona liczbą 58. Natomiast drugą pod względem wyrównoważenia jest konfiguracja 1-4-3-5-2-6, dla której maksymalna wartość niewyrównoważonego momentu jest większa o prawie $68 \%$. Zbliżona do niej pod względem jakości wyrównoważenia jest konfiguracja 1-5-2-4-2-6.

Wyniki obliczeń bezwzględnych maksymalnych wartości momentu od sił bezwładności oraz zakresu ich zmian dla $\lambda=0,3$, zawarte $\mathrm{w}$ tab. 4 , zobrazowano graficznie na rys. 9.

Przebiegi względnych wartości momentu B50 w funkcji kąta obrotu wału korbowego the aid of the counterweights attached to the crankshaft. In this case the optimum modulus of the balancing vector of the relative moment of the primary inertia forces, according to relation (3), is $\Psi^{\prime} / 2$. It can be interesting, therefore, to examine the impact of such degree of balancing of the moment of the primary inertia forces on the resultant moment of the inertia forces for individual crankshaft configuration. In order to calculate the resultant moment $\mathbf{B}_{\mathbf{5 0}}$, after $50 \%$ balancing of its primary constituent, the following formula has been derived on the basis of relations (3) and (4):

$$
\mathrm{B}_{50}=\left\{\begin{array}{l}
{\left[\frac{1}{2} \Psi^{\prime} \sin \left(\alpha-90+\varphi^{\prime}\right)\right]^{2}+} \\
{\left[\frac{1}{2} \Psi^{\prime} \cos \left(\alpha-90+\varphi^{\prime}\right)+\Psi^{\prime \prime} \cos 2\left(\alpha-90+\varphi^{\prime \prime}\right)\right]^{2}}
\end{array}\right.
$$

The values of moment $\mathbf{B}_{\mathbf{5 0}}$ calculated on the grounds of relation (9), for $\lambda=0.3$ and $\lambda=0.5$, for eight best configurations of the crankshaft, are included in Table 4.

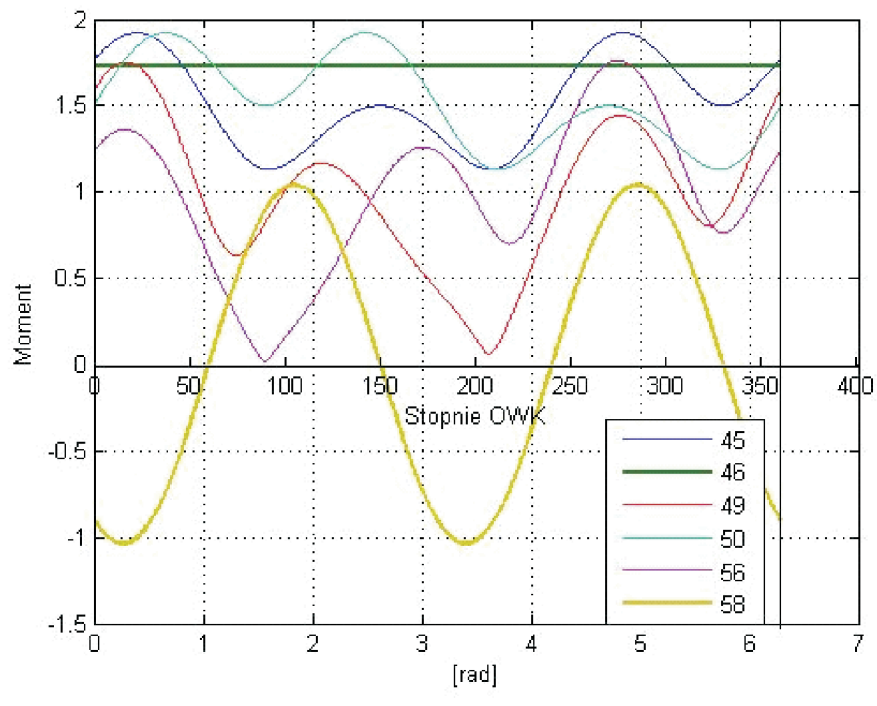

Fig. 10. Influence of the cranks arrangement on the resultant moment $\mathbf{B}_{\mathbf{5 0}}$ of the inertia forces in reciprocating motion for $\lambda=0.3$

Rys. 10. Wplyw konfiguracji watu korbowego na wypadkowy moment $\boldsymbol{B}_{50}$ od sit bezwładności $w$ ruchu postępowo-zwrotnym dla $\lambda=0,3$ 


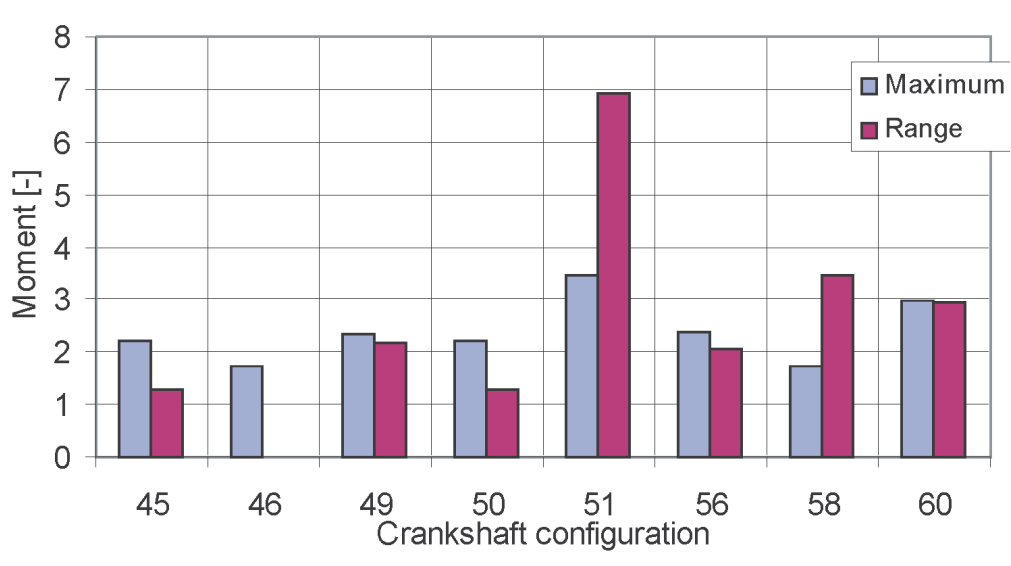

Fig. 11. Bar chart of the relative maximum values of the resultant moment $B_{w}$ and the range of its change for different arrangements of cranks and $\lambda=0.5$

Rys. 11. Wykres stupkowy maksymalnych względnych wartości wypadkowego momentu B50 i zakresu jego zmian dla poszczególnych konfiguracji wału korbowego. dla $\lambda=0,5$

It follows from Table 4 that the configuration 1-5-3-4-2-6 denoted by 58 . commonly used in two-stroke engines is still by far the best from the point of view of the maximum value of the non balanced resultant moment of the inertia forces. The configuration 1-4-3-5-2-6. which is second in turn in terms of the quality of balancing has bigger maximum value of the unbalanced moment by almost $68 \%$. Similar to it in terms of balancing is the configuration $1-5-2-4-2-6$.

The outcomes of the calculations of the absolute maximum values of the moment of inertia forces and their range of change for $\lambda=0.3$ are illustrated in Fig. 9 .

The plots of the moment $\mathbf{B}_{\mathbf{5 0}}$ versus angle of crankshaft travel for the best six configurations and $\lambda=0.3$ are presented in Fig. 10 .

It follows from Table 4 that the moment $\mathbf{B}_{\mathbf{5 0}}$ for configuration No 58 is a harmonic function of the secondary order since the amplitude coefficient of its primary constituent $\Psi^{\prime}=0$. The direction of the vector of the moment for this configuration of the crankshaft is perpendicular to the plane passing through the cylinder axis. The lack of the primary component of the resultant moment of the inertia forces means that the application of counterweights on the continuations of the crank webs is unnecessary unless the purpose is the reduction of the bending moment of the crankshaft and therefore also its deformations. It is worth to notice that for the remaining configurations in Fig. 10 with the exception of 46 . vector $\mathbf{B}_{\mathbf{5 0}}$ has a varied magnitude and rotates with a changing speed in the direction opposite to the crankshaft. For the configuration 46 the locus of the ends of the vector $\mathbf{B}_{50}$ is a circle. The vector has therefore constant modulus and rotates with the same angular velocity as the crankshaft but in the opposite direction. dla czterech najlepszych konfiguracji, dla $\lambda=0,3$ przedstawiono na rys. 10 .

Jak wynika $\mathrm{z}$ tabeli 4 , moment $\mathbf{B}_{\mathbf{5 0}}$ dla konfiguracji nr 58 jest funkcją harmoniczną drugiego rzędu, gdyż współczynnik amplitudy składowej pierwszego rzędu $\Psi^{\prime}=0$. Kierunek wektora momentu dla tej konfiguracji jest stały i prostopadły do płaszczyzny utworzonej przez osie cylindrów. Brak składowej pierwszego rzędu oznacza, że zastosowanie przeciwmas na przedłużeniu ramion poszczególnych wykorbień w silniku o konfiguracji 58 jest niepotrzebne, chyba że ich celem byłoby wyłącznie zmniejszenie momentu gnącego wał, a zatem i jego odkształceń. Warto zauważyć, że dla pozostałych konfiguracji na rys. 10 wektor $\mathbf{B}_{\mathbf{5 0}}$ ma zmienny moduł i wiruje ze zmienną prędkością kątową w kierunku przeciwnym do obrotu wału korbowego, z tym że dla konfiguracji 46 miejscem geometrycznym końców wektora $\mathbf{B}_{50}$ jest okrąg. Wektor ten ma więc stały moduł i wiruje ze taką samą prędkością kątową jak wał korbowy, ale $\mathrm{w}$ przeciwnym kierunku.

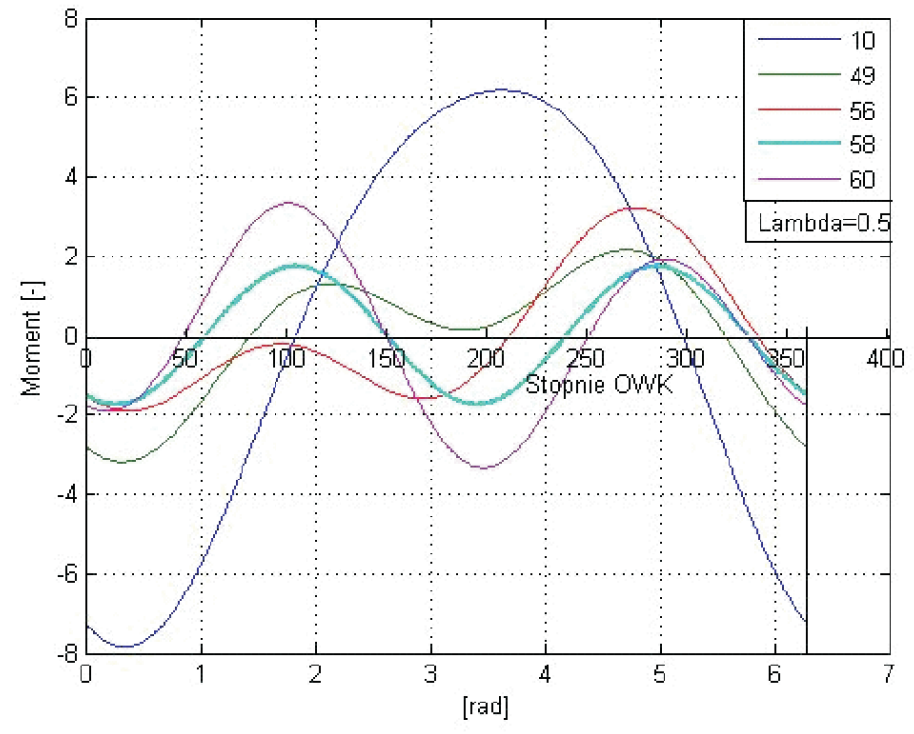

Fig. 12. Influence of cranks arrangement on the resultant moment $\mathbf{B}_{\mathbf{5 0}}$ of the inertia forces in reciprocating motion for $\lambda=0.5$

Rys. 12. Wplyw konfiguracji watu korbowego na wypadkowy moment $\mathbf{B}_{50}$ od sit bezwladności $w$ ruchu postępowo-zwrotnym dla $\lambda=0,5$

Podobne obliczenia maksymalnego momentu i zakresu jego zmian wykonano dla parametru $\lambda=0,5$. Wyniki obliczeń zobrazowano graficznie na rys. 11, a przebiegi momentów w funkcji kąta obrotu wału korbowego przedstawiono na rys. 12 .

Jak wynika z rys.12, konfiguracja 46 zrównała się pod względem jakości wyrównoważenia $\mathrm{z}$ dotychczas najlepszą konfiguracją 58. Od tych dwu konfiguracji niewiele odbiegają pozostałe przedstawione na rys.12. Jednakowe 
Similar calculations of the maximum moment and the range of its change were made for $\lambda=0.5$. The outcomes of the calculations are illustrated graphically in Fig. 11 and the plots of the moments versus angle of crankshaft travel are presented in Fig. 12.

It can be seen from Fig. 12 that configuration 46 equalled with the best so far configuration 58 . The remaining configurations in Fig. 12 not much diverge from the above two. To be specific the configurations 45 and 50. which are mutually equivalent. have bigger the maximum value of the moment $\mathbf{B}_{\mathbf{5 0}}$ than configurations 46 and 58 by $28 \%$ and the configurations 49 and 56 by $33.6 \%$ and $36.5 \%$ respectively.

\section{Conclusions}

The mathematical relations for all configurations of the crankshaft derived for the purposes of this paper enable simple analysis each of them with respect to quality of balancing. The outcomes of the analysis indicate that the simple graphical method used by IC engine experts is valid also for the crank gears applied in the long-stroke engines used as the main drive of ships for which the parameter $\lambda$ reaches values close to 0.5 . The boundary value of $\lambda$ above which the graphical method looses its validity. is 1 . However this value has only a theoretical sense.

The advantage of the configuration 1-5-3-4-2-6 included in the Table 1 under item 58 over the next one decreases with the increase in the value of parameter 1 but the unbalanced moment of the inertia forces in reciprocating motion has the smallest value even for the crank gear with $\lambda=0.5$. The next in terms of balancing configurations 56.60 and 49 have bigger values of unbalanced moment than configuration 58 by $86 \%, 92 \%$ and $95 \%$ respectively for this value of 1 . The situation changes quite substantially for $\lambda=0.5$ where the configurations are analysed and compared after $50 \%$ balancing of the primary component of the moment with counterweights attached to the crankshaft. In such a case configuration 46 equals in terms of balancing with commonly used configuration 58. instead the mutually equivalent configurations 45 and 50 are worse only by $28 \%$ from the best ones and configurations 49 and 56 by $35.6 \%$ and $36.5 \%$ respectively. pod względem wyrównoważenia konfiguracje 45 i 50 mają maksymalną wartość momentu $\mathbf{B}_{50}$ większą o $28 \%$, a konfiguracje 49 i 56 odpowiednio o 35,6 i 36,5\% od konfiguracji 46 i 58.

\section{Zakończenie i wnioski}

Wyprowadzone na potrzeby pracy zależności dla wszystkich 60 konfiguracji wału korbowego pozwalają na analizę każdej z nich pod kątem wyrównoważenia silnika. Wyniki analizy wskazują, że stosowany przez silnikowców prosty schemat graficzny wyboru optymalnej konfiguracji wału korbowego jest słuszny także dla mechanizmów korbowych stosowanych w tzw. silnikach długoskokowych przeznaczonych do napędu głównego statków, dla których parametr mechanizmu korbowego $\lambda$ osiąga wartości bliskie 0,5 . Wartością graniczną parametru $\lambda$, powyżej której schemat ten traci ważność, jest liczba 1. Jednakże tak duża wartość $\lambda$ ma jedynie teoretyczne znaczenie. Przewaga konfiguracji 1-5-3-4-2-6 zamieszczonej w tab. 4 pod pozycją 58 nad kolejną maleje wraz ze wzrostem parametru $\lambda$, ale niewyrównoważony moment od sił bezwładności w ruchu postępowo-zwrotnym dla tej konfiguracji jest wciąż najmniejszy, nawet dla mechanizmu korbowego o $\lambda=0,5$. Dla tej wartości $\lambda$ kolejne pod względem maksymalnego momentu od sił bezwładności konfiguracje 56, 60 i 49 mają wartości momentu odpowiednio o 86, 92 i 95\% większe niż konfiguracja 58. Sytuacja ulega dość istotnej zmianie dla $\lambda=0,5$, gdy analizuje się i porównuje poszczególne konfiguracje po 50-procentowym wyrównoważeniu składowej momentu pierwszego rzędu za pomocą przeciwmas umieszczonych na wale korbowym. W takim przypadku konfiguracja 46 zrównuje się pod względem jakości wyrównoważenia z powszechnie stosowaną konfiguracją 58, natomiast równoważne sobie pod względem wyrównoważenia konfiguracje 45 i 50 są tylko o $28 \%$ gorsze, a konfiguracje 49 i 56 są gorsze od najlepszych tylko odpowiednio o 35,6 i $36,5 \%$.

Paper reviewed

\section{Bibliography/Literatura}

[1] Mosakowski R.: Analiza wyrównoważenia silników rzędowych dwusuwowych czterocylindrowych, Archiwum Motoryzacji nr 4, 2006.

[2] Mosakowski R.: Uwagi na temat graficznej metody analizy wyrównoważenia wielocylindrowych silników rzędowych, Archiwum Motoryzacji nr 4, 1999.

[3] Jędrzejowski J.: Mechanika układów korbowych silników samochodowych, WKiŁ, Warszawa 1972.

[4] Niewiarowski K.: Tłokowe silniki spalinowe, WKiŁ, Warszawa 1983.
[5] Mosakowski R.: Analiza wyrównoważenia silników 6-cylindrowych dwusuwowych, Opracowanie wewnętrzne Wydziału Mechanicznego Politechniki Gdańskiej.

Mr. Ryszard Mosakowski. DEng. - doctor in the Mechanical Engineering Faculty at Gdańsk University of Technology.

Dr inż. Ryszard Mosakowski - adiunkt na Wydziale Mechanicznym Politechniki Gdańskiej. e-mail: rmosakow@pg.gda.pl 